\begin{tabular}{|l|l|l||}
\hline \multicolumn{2}{|c|}{ PublisherInfo } \\
\hline \hline PublisherName & $:$ & BioMed Central \\
\hline \hline PublisherLocation & $:$ & London \\
\hline \hline PublisherImprintName & $:$ & BioMed Central \\
\hline \hline
\end{tabular}

\title{
Mouse, fly wound repair linked
}

\begin{tabular}{|l|l|l||}
\hline \multicolumn{2}{|c|}{ ArticleInfo } \\
\hline \hline ArticleID & $:$ & 5077 \\
\hline \hline ArticleDOI & $:$ & $10.1186 /$ gb-spotlight-20050415-01 \\
\hline \hline ArticleCitationID & $:$ & spotlight-20050415-01 \\
\hline \hline ArticleSequenceNumber & $:$ & 53 \\
\hline \hline ArticleCategory & $:$ & Research news \\
\hline ArticleFirstPage & $:$ & 1 \\
\hline \hline ArticleLastPage & $:$ & 3 \\
\hline \hline & & RegistrationDate : 2005-4-15 \\
\hline ArticleHistory & $:$ & OnlineDate \\
\hline \hline ArticleCopyright & $:$ & BioMed Central Ltd2005-4-15 \\
\hline \hline ArticleGrants & $:$ & \\
\hline \hline ArticleContext & $:$ & 130596611 \\
\hline \hline
\end{tabular}


The same family of transcription factors directs the repair of epidermal wounds in mice and flies, two research teams report in this week's Science. Their unexpected findings may help clarify the signal pathways that initiate outer barrier repair in a range of organisms.

"Until now, there was no reason to suspect common genetic control pathways in the repair of mammal skin and insect cuticle, because the proteins they are built with are completely different," coauthor William McGinnis of the University of California at San Diego told The Scientist.

Little was known about the signaling pathways that direct repair of the surface epithelium, McGinnis said. He and his colleagues investigated the genes $D d c$ and pale, which encode DOPA decarboxylase and tyrosine hydroxylase, respectively, in late-stage fly embryos. Both enzymes catalyze quinone production to cross-link proteins and chitins during cuticle formation.

Using in situ hybridization, the researchers found $D d c$ and pale transcripts in epidermal cells within 30 minutes of injury with a sterile needle, suggesting these genes are direct targets of a wound-induced signaling pathway. Deletion analyses revealed reporter sequences upstream from $D d c$ and pale that activate near wounds.

$D d c$ and pale mutants have almost no melanization and sclerotization of the head skeleton, phenotypes similar to flies with mutant grainy head (Grh) transcription factor. DNA sequence analyses revealed the $D d c$ and palewound response reporters possessed consensus binding sites for Grh, suggesting Grh directly regulates both genes.

In a complementary study, Stephen Jane at the Bone Marrow Donor Institute in Melbourne, Australia, and colleagues looked in mice embryos at Grhl3, a Grh-like transcription factor. Mice with mutant Grhl3 displayed minimal signs of healing after wounding compared with normal, a phenotype similar to mice with mutant transglutaminase 1, TGase1, which cross-links proteins and lipids in the stratum corneum. Northern analysis revealed TGasel expression in the epidermis of Grhl3 mutant mice was greatly reduced.

To determine whether TGasel was a Grhl3 target gene, Jane and colleagues performed cyclic amplification and selection of targets (CASTing) to define the consensus binding site of Grhl3, using cellular extracts from an epidermoid carcinoma cell line transfected with a hemagglutinin epitope-tagged Grhl3-containing expression vector. After six cycles, the population of selected binding sites was cloned and individual isolates sequenced and aligned. This revealed a $\mathrm{Grhl} 3 \mathrm{consensus}$ binding site identical to that of Drosophila Grh. Sequence analysis found two good matches for this consensus site upstream of the TGasel transcription start site, and electrophoretic mobility shift assays suggest these sequences bind to Grhl3.

"We have these reporter genes that get turned on as far as 10 cell diameters from wounds, but we don't know what signals activate them or what receptors receive those signals," McGinnis said. In future, he plans to insert their wound response reporters "into a variety of mutant Drosophila and see, after wounding them, whether these wound response reporters are inactive or overexpressed." 
Both McGinnis' and Jane's teams noted that homologs of Grh are highly conserved from Caenorhabditis elegans to humans. "We're going to look at some jellyfish and other simple animals to see if grainy head is expressed in the epidermis, to see how far back in animal evolution this goes," McGinnis said. "There could be relevance for human health someday - once you understand the controls better, you might speed up regeneration of the outer barrier, or slow it down to prevent too much scarring."

Michael Galko of Stanford University in California, who did not participate in this study, noted that a lot of heated debate existed over what signals activate repair programs - either wound-induced release of intracellular factors or changes in cell mechanical tension. "Hopefully, this research can help tease apart what signals transduce repair pathways, by looking at mutants that fit into a well characterized mechanotransduction pathway or mutants that code for some abundant intracellular proteins," he told The Scientist.

"The insights into the mechanism of repair of these outer barriers are just the start point. In terms of re-epithelialization, the movement of cells to seal a hole, it would be interesting if this is reused in the context of development, such as in neural tube closure," Nicholas Harden at Simon Fraser University in Burnaby, Canada, who did not participate in this study, told The Scientist.

\section{References}

1. William McGinnis, [http://www-biology.ucsd.edu/faculty/mcginnis.html]

2. K.A. Mace et al., "An epidermal barrier wound repair pathway in Drosophila is mediated by grainy head," Science, 308:381-5, April 15, 2005., [http://www.sciencemag.org]

3. Stephen Jane, [http://www.bmdi.org.au/default.asp?id=37]

4. S.B. Ting et al., "A homolog of Drosophila grainy head is essential for epidermal integrity in mice," Science, 308:411-3, April 15, 2005., [http://www.sciencemag.org]

5. Nicholas Harden, [http://www.sfu.ca/mbb/mbb/faculty/harden/harden.html] 